\title{
Clinical, biometric and ultrasound assessment of the effects of daily use of a nutraceutical composed of lycopene, acerola extract, grape seed extract and Biomarine Complex in photoaged human skin
}

Avaliações clínica, biométrica e ultrassonográfica dos efeitos do uso diário de um nutracêutico a base de licopeno, extrato de acerola, extrato de semente de uva e Complexo Biomarinho na pele fotoenvelhecida humana

Adilson Costa ${ }^{1}$

Lúcia Helena Fávaro Arruda ${ }^{3}$

Fernanda Sayuri Ota ${ }^{4}$
Lars Lindmark ${ }^{2}$

Elvira Cancio Assumpção ${ }^{4}$

Margareth de Oliveira Pereira ${ }^{4}$

Stéphanie Selma Barros Langen ${ }^{4}$

\begin{abstract}
BACKGROUND: The use of nutraceuticals has become frequent in the cutaneous approach to photoaging.
OBjECTIVES: To assess the clinical efficacy of a nutraceutical product composed of lycopene, acerola extract, grape seed extract and Biomarine ComplexT in photoaged human skin.

METHODS: 50 women, from 35 to 60 years of age, phototypes I to III, were assessed. For 120 days, they associated the nutraceutical product with the use of a sunscreen FPS15. On days 0 (D0), 30 (D30), 60 (D60), 90 (D90) and 120 (D120) they were evaluated and underwent Medical Assessments and Self-Assessment and cutaneous biometric analyses (corneometry, sebumetry and pH-metry) in the skin of the left zygomatic region and the upper medial side region of the left arm; on days 0 (D0), 30 (D30) and 120 (D120) the skin of the same regions was analyzed by ultrasound. On days 0 (D0) and 120 (D120) skin biopsies were performed in the areas where instrumental evaluation was performed (to evaluate collagen and elastic fibers).

RESULTS: There was an improvement of the general status of the skin of all volunteers by the Medical and Volunteer Self- Assessments; increased parameters of cutaneous hydration, reduction of $\mathrm{pH}$, increasing of ultrasound density and a histological increment of collagen and elastic fibers (both on the face and arm); there was a reduction of seborrhea (only on the face)

Conclusions: The daily use of a nutraceutical product containing lycopene, acerola extract, grape seed extract and Biomarine ComplexT showed an important adjuvant effect to counteract skin photoaging.
\end{abstract}

Keywords: Ascorbic acid; Dietary supplements; Skin aging

Resumo: FundanENTOS: O uso de nutracêuticos se tornou uma condição frequente na abordagem cutânea do fotoenvelhecimento.

Oвjetrvos: Avaliar a eficácia clínica do uso de um produto nutracêutico a base de licopeno, extrato de acerola, extrato de semente de uva e Complexo BiomarinhoT na pele fotoenvelhecida humana.

MÉTODOs: Foram avaliadas 50 mulheres, de 35 a 60 anos de idade, fototipo I a III. Por 120 dias, elas associaram ao uso de fotoprotetor FPS15 a tomada diária do produto nutracêutico em questão. Nos dias 0 (D0), 30 (D30), 60 (D60), 90 (D90) e 120 (D120) elas foram avaliadas, quando sofreram Avaliações Médica e Auto-Avaliação e análises biométricas cutâneas (corneometria, sebumetria e pHmetria) nas peles da região zigomática esquerda e face súpero-medial do braço esquerdos; nos dias 0 (D0), 30 (D30) e 120 (D120) a pele das mesmas regiões foram analisadas do ponto de vista ultrassonográfico. Nos dias 0 (D0) e 120 (D120) biópsias cutâneas foram realizadas nas respectivas áreas das análises instrumentais (para avaliar colágeno e das fibras elásticas).

REsutTADOS: Houve melhora do estado geral da pele de todas as voluntárias pelas Avaliações Médica e Voluntária; aumento alterações dos parâmetros cutâneos na hidratação, redução do pH cutâneo, aumento da densidade ultrassonográfica e aumento histológico na densidade colágena e elástica (tanto na face quanto no braço); redução da seborreia somente na face.

CONCLusões: O uso diário de um produto nutracêutico a base de licopeno, extrato de acerola, extrato de semente de uva e Complexo BiomarinhoT mostra-se um adjuvante importante na abordagem do fotoenvelhecimento cutâneo.

Palavras-chave: Ácido ascórbico; Envelhecimento da pele; Suplementos dietéticos;

Received on 11.12.2010.

Approved by the Advisory Board and accepted for publication on 24.03.11

* Work performed at a private clinic - Campinas (SP), Brasil.

Conflict of interest: None / Conflito de interesse: Nenhum

Financial funding / Suporte financeiro: All expenses related to the study were sponsored by "Ferrosan do Brasil Ltda."

Master in Dermatology by the "Universidade Federal de São Paulo" (UNIFESP); PhD degree in course by the School of Medicine "Universidade de São Paulo" (FMUSP) - Coordinator of the Acne, Cosmetic Dermatology, Dermatology in Pregnancy and Clinical Trial Clinics at the "Pontifícia Universidade Católica de Campinas" (PUC-Campinas) - Campinas (SP), Brazil.

Nutritionist, Ph.D. in Medicine by the Gothenburg University, Sweden; - President of Kasima Medical Development AB, Sweden; Chairman of Lipidco Institute of Nutrition and Health, Sweden.

Master in Dermatology by the "Universidade Federal de São Paulo" (UNIFESP); PhD degree in course by the School of Medicine - Universidade de São Paulo (FMUSP) - Chief of the Service of Dermatology at the Pontifícia Universidade Católica de Campinas (PUC-Campinas) - Campinas (SP), Brazil.

Medical doctor - student of the specialization course in Dermatology at the Pontifícia Universidade Católica de Campinas (PUC-Campinas) - Campinas (SP), Brazil. 


\section{INTRODUCTION}

Skin aging is a process that involves genetic, environmental and hormonal mechanisms, resulting from intrinsic (chronological) and extrinsic (environmental) components occurring simultaneously. ${ }^{1}$ Free radicals play an essential role on these extrinsic and intrinsic components. They act directly on the growth factors and receptors of cytokines in the keratinocytes and dermal cells, leading to skin inflammation. ${ }^{2}$

In the chronological aging, free radicals are naturally formed in the human metabolism; however, in the extrinsic aging, they are produced by external factors, such as exposure to ultraviolet (UV) rays, smoking and alcohol consumption. ${ }^{2} \mathrm{UV}$ rays are the most important factor in extrinsic aging and plays a fundamental role in the etiology of photoaging and skin cancer. ${ }^{1-3}$ At least $50 \%$ of skin damage induced by UV rays may be attributed to the formation of free radicals induced by these rays. ${ }^{2}$

The UV radiation penetrates into the skin and, depending on the wavelength, it interacts with different cells located on the different layers. The shortwave (UVB) radiation is primarily absorbed in the epidermis and predominantly affects the keratinocytes, while the longer waves (UVA) penetrate to a deeper level, affecting both the keratinocytes of the epidermis and the fibroblasts of the dermis. ${ }^{2}$ Each type of wave acts in a specific manner. Due to the generation of ROS, the UVA indirectly produces mutations in the mitochondrial DNA, important in the physiopathogenesis of the skin aging; the UVB radiation directly damages the DNA, being related to premalignant skin damage and skin cancer. ${ }^{1-4}$

In view of the present knowledge it can be assumed that photoaging is a cumulative process that depends on the degree of sun exposure and cutaneous pigmentation. ${ }^{1}$ Continuous and recurrent sun exposure causes permanent changes in the quantity and distribution of the melanin in the skin. The presence of amorphous material in the papillary dermis, instead of connective tissue, is considered a main element to distinguish chronological aging from photoaging. ${ }^{1 \cdot 3}$

When the skin is chronically exposed to the sun, changes occur in the dermis and epidermis. In the latter the stratum corneum is thickened, the epidermis becomes acanthotic and dysplasia with cellular atypia and anaplasia occurs. The keratinocytes become irregular with the loss of polarity and the melanocytes are distributed in an irregular manner. There is also a decrease in the quantity of Langerhans cells, which explains the immunossupression. ${ }^{1,2}$

The histopathological dermal changes in the photoaging are represented by the decrease of collagen and its precursors, in addition to the degenera- tion of elastic fibers, which are replaced by an amorphous mass. The inflammatory process thus generated leads to an increase of mast cells, macrophages and lymphocytes. Moreover, blood vessels become more fragile and may easily break apart, resulting in purpuric lesions. ${ }^{1,2}$

Various antioxidants have been used for different types of diseases. Most of them have important biological properties, such as, for example, anti-carcinogenic and anti-inflammatory action. ${ }^{2}$ There is growing evidence that dietary antioxidants, such as carotenoids, tocopherols and ascorbic acid, protect against photo oxidative reactions and may be useful in preventing diseases related to the stress caused by the free radicals. ${ }^{4,5}$

Among these antioxidants provided by dietary supplementation, vitamin $\mathrm{C}$ plays an important role due to its use for a long time. An important source of such vitamin is the acerola extract, which is one of the important fruits that provide such antioxidants. ${ }^{6}$ The benefits obtained with the therapeutic use of vitamin $\mathrm{C}$ in biological trials with animals include the protective effect against damage caused by exposure to radiation and drugs. ${ }^{\top}$ Epidemiological studies also attribute to this vitamin a possible role of protection against the development of tumors in humans, in addition to dietary needs which are essential for the collagen synthesis. ${ }^{8.9}$

Another antioxidant compound found in nutraceuticals is the lycopene. It is a derivative of carotenoids found in fruits and vegetables, giving a red color to the latter ones. Its preventive effect against photoinduced cell damage has already been proved in studies with rats. For this reason, it is already included in several dermatological products. Its chemopreventive reported effect includes a wide range of epithelial cancers, including lung cancer., ${ }^{2,10}$

The carotenoids are present in the human skin and contribute to the UV protection. For this reason, the oral supplementation with carotene provides a moderate protection against erythema induced by UV rays. Fruits and vegetables are the main source of carotenoid from the diet: xanthophylls, such as lutein and zeaxanthin, are found in green leafy vegetables or in corn; lycopene is a carotenoid predominant in tomatoes. In vitro and in vivo studies demonstrate that carotenoids can decrease the risk of various diseases by scavenging of singlet oxygen or peroxyl radical, removing peroxide radicals, modulating carcinogenic metabolism, inhibiting cellular proliferation, stimulating gap-junctions and increasing the immune response..$^{10-12}$

Recently, grape compounds have been especially used in nutraceuticals. The grape seeds and peel contain flavonoids (catechin, epicatechin, procyani- 
dins and anthocyanins), phenol acids and resveratrol, all of which have functional activities. The procyanidins, for instance, present an in vivo antioxidant activity and could be as important as vitamin $\mathrm{E}$ in preventing oxidative damage in tissues, reducing lipid oxidation and/or inhibiting free radical production. ${ }^{13,14}$

The use of modern substances, associated with those already classically used in nutraceuticals, have been, in the last years, good alternatives in the approach to skin aging. Recently, the addition of a Biomarine Complex ${ }^{\mathrm{TM}}$, an extract rich in marine proteins and polysaccharides, in oral skin care opens the potential for significant benefits for the aging skin. ${ }^{15,16}$

The present study was performed in Brazilian women as a longitudinal study to assess how Brazilian skin responds to a known oral skin supplement. The aim was to repeatedly assess skin quality using subjective and objective variables as well as using skin biopsies.

\section{MATERIALS AND METHODS}

The present study is a single stage, phase IV, prospective, non-comparative, open clinical study, approved by the University Ethics Committee in Research in Human Beings. After being instructed and having agreed with the study procedures, by the signing the Free and Explained Consent Term, 50 women between 35 and 60 years of age, phototypes I to III, habitual users of only sunscreen with SPF 15 for, at least, 60 days, were included in the study.

The following exclusion criteria were considered: smoking, daily sun exposure, use of cosmetics in the assessment sites and/or of any other nutraceutical, presenting, during the study, with any dermatosis, systemic disease or need of use of medicines and/or products that hinder the clinical assessment of this treatment, intense sun exposure 60 days before the study, pregnancy or lactation. The appearance of any condition listed as exclusion criteria and the non-use of the therapeutic regimen for 7 consecutive days or 15 alternate days, both in total and in part, were reasons for exclusion from the study.

After the inclusion of the volunteers (Visit 1, D0), they were instructed to use, for 120 days, Imedeen $^{\circledR}$ Time Perfection (105mg of Biomarine Complex $^{\mathrm{TM}}$, an extract composed of marine proteins and polysaccharides; $14.8 \mathrm{mg}$ of Lycophence ${ }^{\circledR}$ GS, composed of lycopene and grape seed extract; $30 \mathrm{mg}$ of acerola extract - Ferrosan A/S, Copenhagen, Denmark), 2 tablets a day, together with lunch or dinner, in a single intake, associated with the use of Episol $^{\circledR}$ SPF 15 lotion (Mantecorp Indústria Química e Farmacêutica Ltda., Rio de Janeiro, Brazil) on the face, in the morning and at lunch time.

On Visits 2 (D30), 3 (D60), 4 (D90) and 5 (D120), the volunteers were photographed (Canon ${ }^{\circledR}$
PowerShot G10 - Tokyo, Japan) and underwent assessment through subjective questionnaires answered by physicians and volunteer self-assessment. The parameters assessed were the improvement of: Wrinkles, Fine Expression Lines, Sun Melanosis, Other Hyperchromias, Erythema, Hydration, Radiance, Sebum, Smoothness and Overall Appearance; the possible response standards were: Maintained, Discrete, Moderate, Accentuated and Complete. In these same visits, corneometry, sebumetry and pH-metry (Derma Unit SSC3, Courage+Khazaka Eletronic - Köln, Germany) were also carried out in the left zygomatic region (after removal of sunscreen with tissue paper) and in the upper medial side of the left arm $(04 \mathrm{~cm}$. below the lower limit of setting of the axillary hair), carried out after 20 minutes of waiting in a room acclimatized at $20^{\circ} \mathrm{C}$. On Visits 1 (D0), 2 (V30) and 5 (D120), both regions underwent an ultrasound exami-

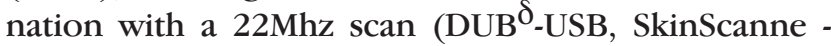
Luneburg, Germany). On Visits 1 (D0) and 5 (D120) skin biopsies were performed (after completion of instrumental evaluations) from both zygomatic left region and upper medial area of the left arm and fragments were stained with Massons trichome and Verhoeff stains in order to obtain, respectively, a subjective histological evaluation of collagen and elastic fibers of the skin, and to compare which type of profiles these fibers could have after 120 days of usage of the nutraceutical product under study. During the study, volunteers could be absent from a single visit, other than D0 or D120 visit, to be eligible for inclusion.

Non-parametric statistical tests according to Anderson-Darling were used, to allow for a non normal distribution standard (Gauss Curve). A significance level of $0.05(5 \%)$ was chosen as statistically significant, with confidence intervals of $95 \%$. In order to analyze the answers obtained from physicians and volunteers questionnaires, the Equality of Two Proportions was used. For corneometry, pH-metry, sebumetry and ultrasound responses, the Wilcoxon test and the Friedman test were used.

\section{RESULTS}

Out of 50 volunteers, 42 (84\%) concluded the study; 8 volunteers did not conclude the study based on personal reasons, with no relation to adverse events (which were not seen in any participant during the study). The average age was 46.3 years; sixteen of them had phototype II and twenty-six had phototype III. Results were obtained from the analyses of the clinical response assessment questionnaires, both from the medical team and from volunteer self-assessment. From D30, that is, 30 days after the use of the product, clinical response standards were attributed, and the results of each item was compared, always in relation 
to $\mathrm{D} 30$. In the Tables, the $p$-values that presented statistical significance $(\mathrm{p}<0.05)$ are shown in red and with an asterisk $(*)$.

Both in the Medical Assessment Questionnaire, and in the Volunteer Self-Assessment Questionnaire, a clinical improvement with the use of the product was observed (which is represented by reduction of responses "Maintained", showing in some clinical items, such as Wrinkles, with a statistically significant response already comparing D60 with D30) in all items, for the medical team, and in the items Wrinkles, Fine Lines, Other Hyperchromias, Hydration, Radiance, Smoothness and Overall Appearance, from the volunteers themselves (Graphics 1 and 2). All of the criteria showed a gradual improvement throughout the time of the clinical study which can be observed in each Figure provided.

From the Medical Assessment, at the end of the study (D120), for each clinical item assessed there were the following statistically significant improve- ment responses: Wrinkles, 45\% Discrete $(\mathrm{p}<0.001)$ and $12 \%$ Moderate $(p=0.021)$; Fine Lines, $29 \%$ Moderate $(\mathrm{p}<0.001) ;$ Melanosis, 52\% Discrete $(\mathrm{p}=0.014)$ and $26 \%$ Moderate $(\mathrm{p}<0.001)$; Other Hyperchromias, 29\% Moderate $(\mathrm{p}<0.001)$; Erythema, $31 \%$ Moderate $(\mathrm{p}<0.001)$ and $12 \%$ Accentuated $(\mathrm{p}=0.0021)$; Hydration, 31\% Moderate $(\mathrm{p}<0.001)$; Radiance, $41 \%$ Moderate $(\mathrm{p}<00.1)$ and $17 \%$ Accentuated $(\mathrm{p}=0.006) ;$ Sebum, 41\% Moderate $(\mathrm{p}=0.001)$; Smoothness, 43\% Moderate $(\mathrm{p}<0.001)$ and $19 \%$ Accentuated $(\mathrm{p}=0.003)$; Overall Appearance, $38 \%$ Moderate $(\mathrm{p}<0.001)$ and $10 \%$ Accentuated $(\mathrm{p}=0.04)$.

From the Volunteer Assessment, at the end of the study (D120), for each item assessed there were the following statistically significant improvement responses: Wrinkles, 38\% Accentuated $(\mathrm{p}<0.001)$; Fine Lines, $\quad 38 \%$ Accentuated $\quad(p=0.002) ; \quad$ Other Hyperchromias, $14 \%$ Accentuated $(p=0.048)$ Hydration, $10 \%$ Discrete $(\mathrm{p}<0.001)$, 50\% Accentuated

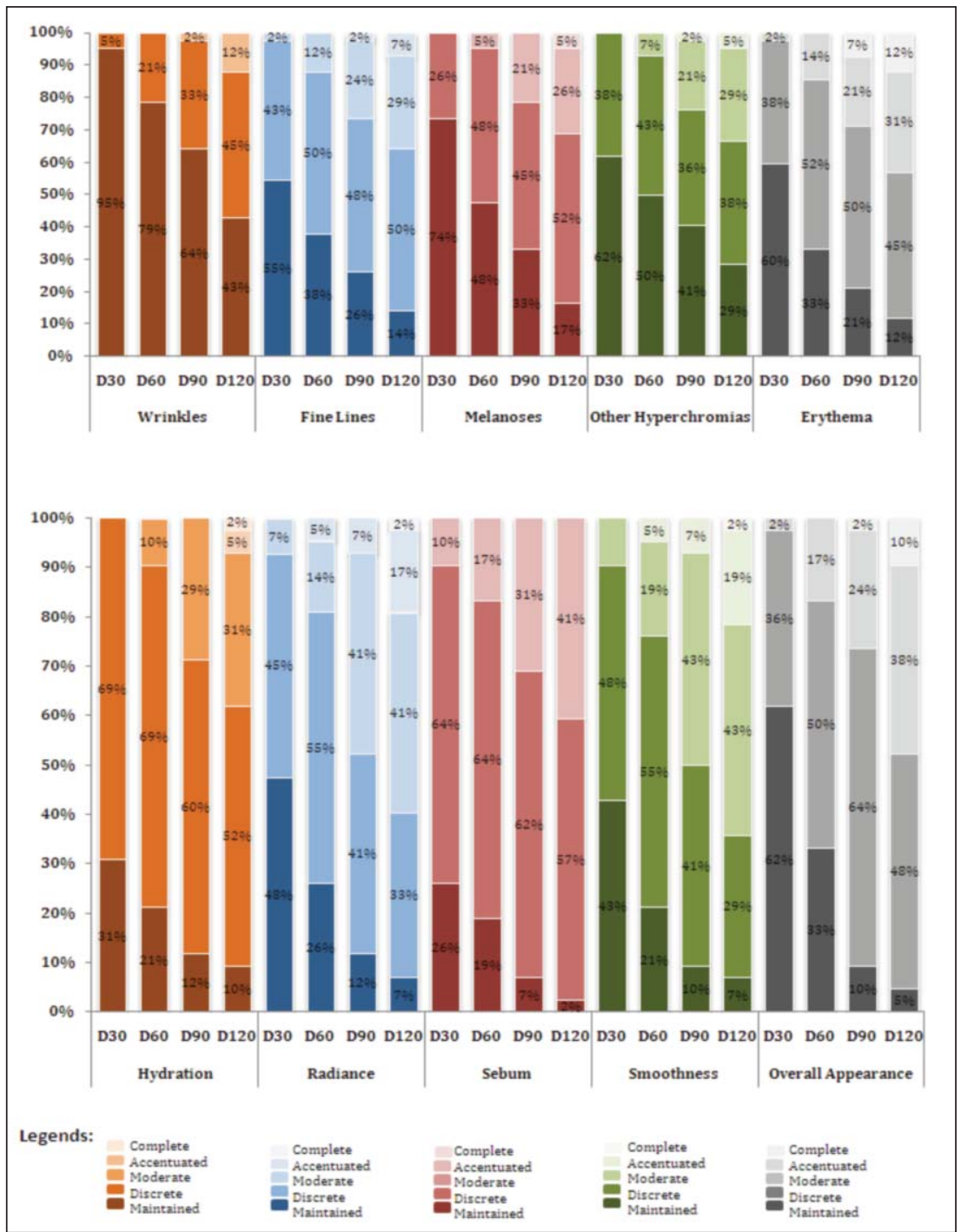

GraPHIC 1: Distribution of medical assessment questionnaire of therapeutic clinical evolution 
$(\mathrm{p}=0.003), 21 \%$ Complete $(\mathrm{p}=0.0024)$; Radiance $10 \%$ Discrete $(\mathrm{p}<00.1)$ and $48 \%$ Accentuated $(\mathrm{p}<0.001)$; Smoothness, 14\% Discrete $(\mathrm{p}=0.004)$ e $43 \%$ Accentuated $(\mathrm{p}<0.001)$; Overall Appearance, $7 \%$ Discrete $(\mathrm{p}<0.001), 33 \%$ Moderate $(\mathrm{p}=0.003)$ and $45 \%$ Accentuated $(\mathrm{p}=0.01)$.

Comparing the beginning (D0) with the end of the study (D120), in regards to corneometry and $\mathrm{pH}$ metry, we noted that there were, respectively, an increase $(25.41 \%$, that is, from 50.85 to 63.77 , on the face; $35.17 \%$, that is, from 39.95 to 54 , on the arm) and a reduction $(10.37 \%$, that is, from 5.59 to 5.01 , on the face; $10.10 \%$, that is, from 5.64 to 5.07 , on the arm), visit-to-visit, of the parameter values for both techniques, in both sites $(\mathrm{p}<0.001)$ (Table 1 , Graphic 3 ). This shows that there was an improvement of skin hydration and a reduction of the $\mathrm{pH}$ (acidification) of the skin. In regards to sebumetry, we noted an instrumental change only on the face, as the changes on the arm were not statistically significant at the end of study (Table 1, Graphic 3). A $29.26 \%$ reduction was obtained (from $102.7 \mathrm{mg} / \mathrm{cm}^{2}$ to $72.64 \mathrm{mg} / \mathrm{cm}^{2}$, $\mathrm{p}<0.001)$ on this site, which shows a reduction of facial seborrhea.

For the analysis of the dermal density through ultrasound, we noted that there was a gradual increase of values of its parameters during the period of use of the product [face: $49.94 \%$, from 26.31 (D0) to 39.45 (D120), $\mathrm{p}<0.001$; arm: 13.90\%, from 61.71 (D0) to 70.29 (D120), $\mathrm{p}=0.002)$, which is clearly illustrated by the images obtained from the Ultrasound device display (Table 2, Graphic 4 and Figure 1).

According to subjective histological analysis, the dermatopathologist observed an increase of dermal density of collagen [face $(\mathbf{8 8 . 1 \%}$ of volunteers; $\mathrm{p}<0.001)$ and arm $(28.7 \%$ of volunteers; $\mathrm{p}<0.001)$ ], with the same pattern of response to elastic fibers [face $85.7 \%$ of volunteers; $p<0.001)$ and arms $(9.5 \%$ of volunteers; $\mathrm{p}<0.001)$ ], during the 120 days of study (Graphic 5 and Figure 2).

\section{DISCUSSION}

In the chronological aging, free radicals are naturally formed in the human metabolism; however,

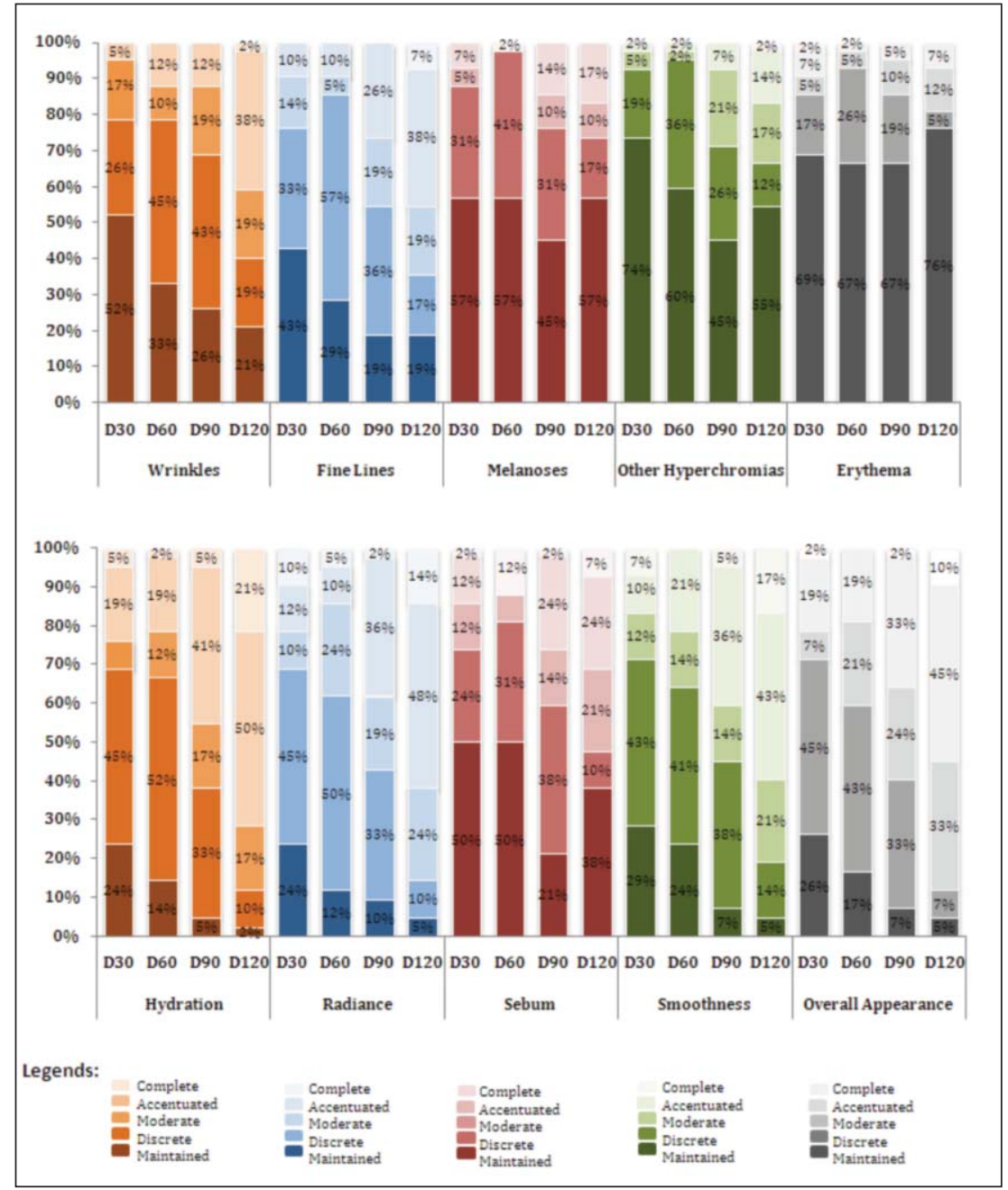

GraPHIC 2: Distribution of volunteer assessment questionnaire of therapeutic clinical evolution 
TABLE 1: Clinical evolution of skin hydrating through corneometry, skin acidification trough pH-metry and skin seborrhea through sebumeter

\begin{tabular}{|c|c|c|c|c|c|c|c|}
\hline & & & Average & Median & $\begin{array}{l}\text { Standard } \\
\text { Deviation }\end{array}$ & $\mathbf{N}$ & p-value \\
\hline \multirow{10}{*}{$\begin{array}{l}\text { Corneometry } \\
\text { (HYDR units) }\end{array}$} & \multirow[t]{5}{*}{ Face } & D0 & 50.85 & 53.0 & 9.86 & 42 & \multirow[t]{5}{*}{$<0.001 *$} \\
\hline & & D30 & 49.14 & 50.1 & 8.72 & 42 & \\
\hline & & D60 & 50.80 & 49.9 & 7.71 & 42 & \\
\hline & & D90 & 61.82 & 61.0 & 10.54 & 42 & \\
\hline & & D120 & 63.77 & 63.0 & 7.73 & 42 & \\
\hline & \multirow[t]{5}{*}{ Left Arm } & D0 & 39.95 & 39.6 & 9.33 & 42 & \multirow[t]{5}{*}{$<0.001 *$} \\
\hline & & D30 & 39.35 & 40.0 & 7.40 & 42 & \\
\hline & & D60 & 42.85 & 42.6 & 9.23 & 42 & \\
\hline & & D90 & 55.70 & 52.7 & 15.84 & 42 & \\
\hline & & D120 & 54.00 & 53.4 & 14.04 & 42 & \\
\hline \multirow[t]{10}{*}{ pH-metry $(\mathrm{pH})$} & \multirow[t]{5}{*}{ Face } & D0 & 5.59 & 5.6 & 0.37 & 42 & \multirow[t]{5}{*}{$<0.001 *$} \\
\hline & & D30 & 5.50 & 5.5 & 0.40 & 42 & \\
\hline & & D60 & 5.18 & 5.2 & 0.34 & 42 & \\
\hline & & D90 & 5.25 & 5.3 & 0.40 & 42 & \\
\hline & & D120 & 5.01 & 5.0 & 0.39 & 42 & \\
\hline & \multirow[t]{5}{*}{ Left Arm } & D0 & 5.64 & 5.6 & 0.52 & 42 & \multirow[t]{5}{*}{$<0.001^{*}$} \\
\hline & & D30 & 5.46 & 5.5 & 0.49 & 42 & \\
\hline & & D60 & 5.24 & 5.3 & 0.42 & 42 & \\
\hline & & D90 & 5.19 & 5.3 & 0.50 & 42 & \\
\hline & & D120 & 5.07 & 5.1 & 0.59 & 42 & \\
\hline \multirow{10}{*}{$\begin{array}{l}\text { Sebumetry } \\
(\mathrm{mg} / \mathrm{cm} 2)\end{array}$} & \multirow[t]{5}{*}{ Face } & D0 & 102.7 & 96 & 53.90 & 42 & \multirow[t]{5}{*}{$<0.001^{*}$} \\
\hline & & D30 & 84.62 & 79 & 47.44 & 42 & \\
\hline & & D60 & 66.21 & 59 & 38.35 & 42 & \\
\hline & & D90 & 71.60 & 68 & 34.01 & 42 & \\
\hline & & D120 & 72.64 & 69 & 40.17 & 42 & \\
\hline & \multirow[t]{5}{*}{ Left Arm } & D0 & 1.45 & 1.0 & 1.92 & 42 & \multirow[t]{5}{*}{0.339} \\
\hline & & D30 & 1.52 & 0.0 & 2.76 & 42 & \\
\hline & & D60 & 2.19 & 0.0 & 3.74 & 42 & \\
\hline & & D90 & 2.29 & 1.0 & 3.08 & 42 & \\
\hline & & D120 & 1.83 & 1.0 & 2.55 & 42 & \\
\hline
\end{tabular}

in the extrinsic aging, they are produced by external factors, such as exposure to UV rays, smoking and alcohol consumption. ${ }^{1,2}$

The presence of endogenous defense mechanisms, such as antioxidant enzymes (superoxide dismutase, catalase, glutathione peroxidase) and nonenzymatic antioxidant molecules (vitamins $\mathrm{C}$ and $\mathrm{E}$, glutathione and ubiquinone), reduce and neutralize these free radical molecules produced during the aging process, protecting the organism against their action. Some of these defense mechanisms may be inhibited by the UV light action (extrinsic aging), as well as having their quantity reduced along the years (intrinsic aging). Thus, these situations reduce such natural defense mechanisms, whilst increasing the production of reactive oxygen species, resulting in skin aging. ${ }^{2,11,17,18}$

Based on this scenario, the use of oral supplement products, known as nutraceuticals, rich in anti- oxidant compounds, assume an important role in the human being's health. Dietary intervention studies in humans, based on the use of antioxidant compounds, show how these compounds may protect us against environmental insults and neutralize sun-induced effects on the skin.

In this study, we noted a clear and significant clinical benefit to signs of skin aging through the daily use of a nutraceutical product, rich in marine proteins and polysaccharides, lycopene, flavonoids and grape procyanidins, as well as vitamin C (Figure 3).

Comparing the results obtained in the study, both in the Medical Assessment and in the Volunteer Assessment, there was an improvement of the Overall Appearance of the skin of the participants.

Studies using Biomarin Complex ${ }^{\mathrm{TM}}$ (105 $\mathrm{mg} /$ tablet) have been reported. An early pilot study from 1990 showed that Biomarine Complex ${ }^{\mathrm{TM}}$ combined with acerola extract (rich in vitamin C) and zinc, 


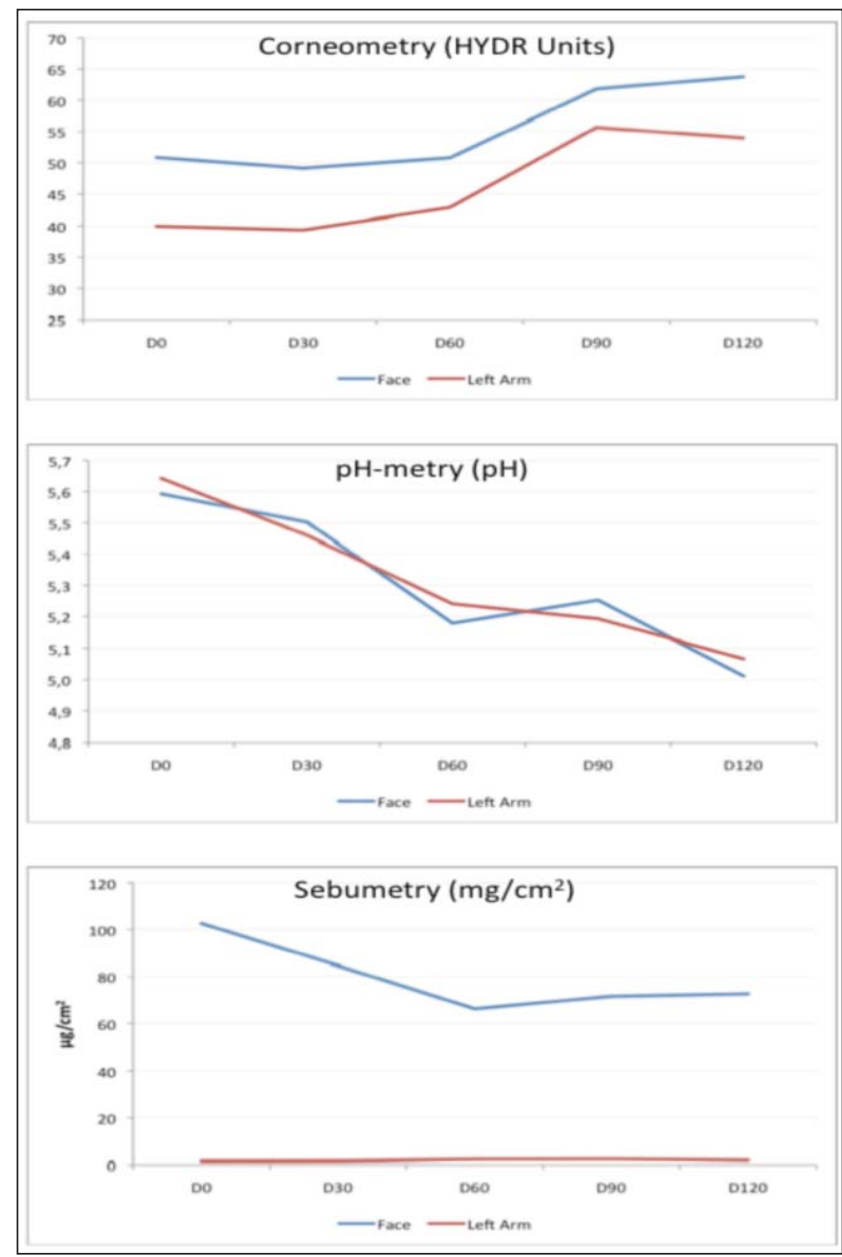

GrAPHIC 3: Clinical evolution of skin hydration through corneometry (HYDR Units), skin acidification through pH-metry $(\mathrm{pH})$ and facial seborrhea through sebumetry $\left(\mathrm{mg} / \mathrm{cm}^{2}\right)$

2 tablets per days for 90 days, had a clinical improvement of fine lines and cutaneous pigmentation. Through the ultrasound assessment of the periocular region, there was an increase of thickness of the epidermis of $8.3 \%$ and of the dermis of $83.3 \%$. Moreover, this instrumental measurement of the facial skin showed a $10 \%$ increase. $^{15}$

Later, 144 volunteers, between 35 and 50 years old, with phototypes II or III, used two tablets daily of a combination of Biomarine Complex ${ }^{\mathrm{TM}}(105 \mathrm{mg})$, vita-

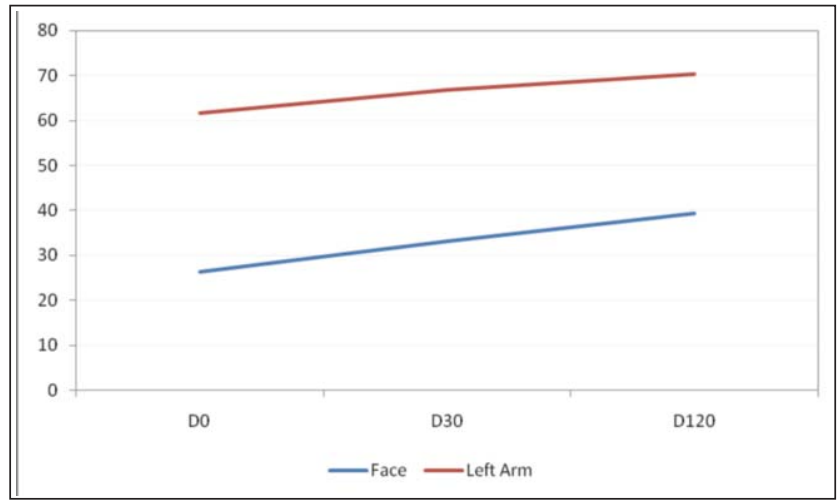

GrAPHIC 4: Changes of ultrasound dermal density (Arbitrary Units, AU) during the study

min $C$ and zinc, for 12 months. During the first 3 months the study was divided into two groups, one (active), another placebo. At the end of this period, there was an increase of the dermal thickness, assessed by ultrasound and a reduction of fine lines, in the group with the related nutraceutical, compared to the placebo group. During the following 9 months, when all the volunteers used the combination, there were an increase of the dermal thickness assessed by ultrasound, both papillary and reticular dermis, a reduction of fine lines, mainly periocular ones, and a reduction of transepidermal water loss. ${ }^{16}$

Additional placebo controlled studies with Biomarin Complex ${ }^{\mathrm{TM}}$ in combination with various nutrients and phytonutrients have been performed in women of both pre and postmenopause age. ${ }^{19,20}$ These studies observed the positive and beneficial results on skin aging by Heule and Kiefer and Eilefsen and are also valid for older skin. ${ }^{20}$

In the present study, we noted that the clinical improvement, with the use of an oral supplement rich in Biomarine Complex ${ }^{\mathrm{TM}}$, confirms what has already been reported in the literature. ${ }^{15,16,19,20}$ The volunteers had an improvement of the signs of skin photoaging, certified both by the dermatologists clinical examination and by the volunteers self-assessment.

In agreement with earlier studies, we also used objective measurements since this is important in

TABLE 2: Changes of ultrasound dermal density (Arbitrary Units, AU) during the study

\begin{tabular}{lllllll}
\hline Dermal Density (AU) & \multicolumn{3}{c}{ Face } & \multicolumn{3}{c}{ Left Arm } \\
\hline & D0 & D30 & D120 & D0 & D30 & D120 \\
Average & 26.31 & 33.26 & 39.45 & 61.71 & 66.79 & 70.29 \\
Median & 26 & 32 & 39 & 63 & 67 & 70 \\
Standard Deviation & 7.20 & 7.71 & 7.73 & 12.43 & 11.46 & 9.49 \\
N & 42 & 42 & 42 & 42 & 42 & 42 \\
p-value & $<0.001^{*}$ & $0.002^{*}$ & & & & \\
\hline
\end{tabular}




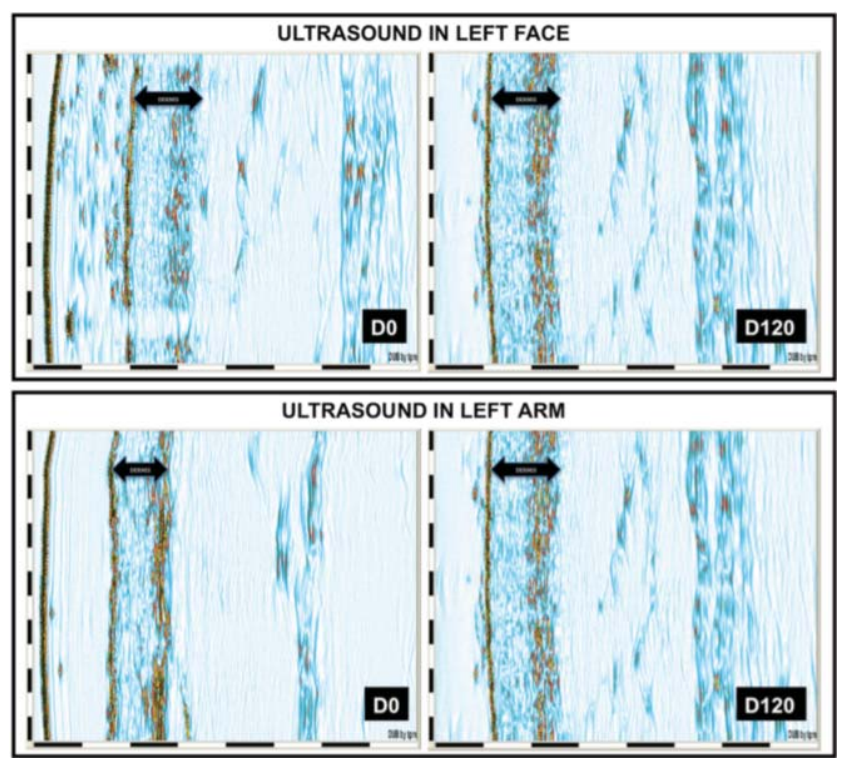

Figure 1: Evolution of ultrasonographic dermal density during the study

Note: The colored points (not blue) represent areas of greater fiber density.

order to assess reproducible and credible effects in the absence of a placebo group. ${ }^{19,20}$ The lack of objective criteria to obtain the clinical response to various treatments, for several dermatosis, is a great challenge in dermatology, which, many times, limits the true registration of the assessed clinical standard, secondary to a certain therapy. Accordingly, we associated three types of modalities to obtain the clinical evolution of the proposed treatment: subject assessment (medical and volunteers), digital photography registration, biometric response instruments such as corneometry, pH-metry, sebumetry and dermal ultrasound scanning.

The epidermal stratum corneum is considered the essential structure for the skin hydration. ${ }^{21,22}$ Its acid character, which is the reason it is also called acid mantle, is essential to establish the permeability of the epidermal barrier and to control the cohesion and integrity of the stratum corneum. ${ }^{23}$ The origin of such acidification arises from three endogenous processes: production of free fatty acids, via secretory phospholipase-A2; production of trans-urocanic acid, from the histidine, catalyzed by histadase; $\mathrm{H}^{+}$ion secretion by $\mathrm{Na}^{+} / \mathrm{H}^{+}$pump. ${ }^{23}$ The acidification of the stratum corneum is essential for the permeability of the epidermal barrier. The recovery process normally occurs in an acid $\mathrm{pH}$, which is postponed in a neutral $\mathrm{pH}$, as the enzymes that secrete the lipids of the bilamellar lipid barrier are activated in an acid $\mathrm{pH}$. This intensifies the cohesion and integrity of the stratum corneum. ${ }^{23}$

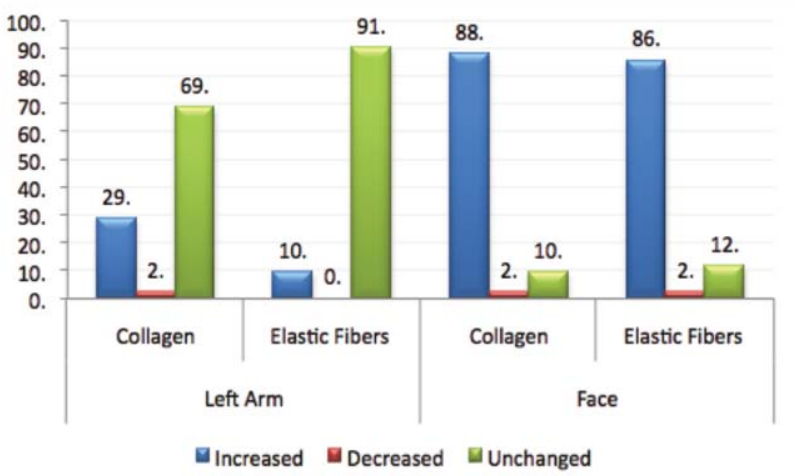

GraPhic 5: Changes of collagen and elastic fibers patterns (histological analysis) during the study

Note: Masson's trichome Stain (both in left face and left arm biopsies) shows increasing of collagen density (fibers are closer) when D120 is compared to D0; Verboeff Stain shows the same response to elastic fibers in both areas of evaluation.

Consequently, such particularities increase the capacity of maintaining the skin hydrated. ${ }^{21,23}$

This study showed an increase of hydrating of the corneal layer $(25.41 \%$, on the face, and $35.17 \%$, on the arm), directly proportional to its $\mathrm{pH}(10.37 \%$, on the face, and $10.10 \%$, on the arm), which is in agreement with the findings in the literature for the usual mechanism of skin hydration. ${ }^{21,23}$ To us this important change of the $\mathrm{pH}$ and its' relation to improved skin hydration is new data not shown before with an oral nutraceutical supplement. Earlier studies have shown general improvement in skin hydration, but with little understanding of cause and effect.

Cutaneous xerosis is an important sign of cutaneous dehydration. ${ }^{21,22}$ Lycopene, a carotenoid antioxidant, may be involved in the clinical results found in the present study, since its presence, in higher concentrations in the skin, reduces the cutaneous xerosis, which is the initial stage of the formation of wrinkles. ${ }^{24}$

Acerola is also used in nutraceutical products, due to its high content of vitamin $\mathrm{C}$, which is able to scavenge free radicals with great efficiency, in addition to having effect against the damage caused by the exposure to radiations. ${ }^{7-9}$ Vitamin $C$ contributes to the formation of the epidermal barrier as it increases the epidermal differentiation and stimulates the blood flow through the production of nitric oxide. ${ }^{24}$

Another reason that could have helped to improve the skin hydrating is the fact that the oral intake of polyphenols prevents the change of the epidermal barrier by increasing the skin tolerance to the UVB action. ${ }^{24}$ Grape seed extract used in the present trial, is a product is rich in polyphenols, many with flavonoid structure. In vitro studies with flavonoids 


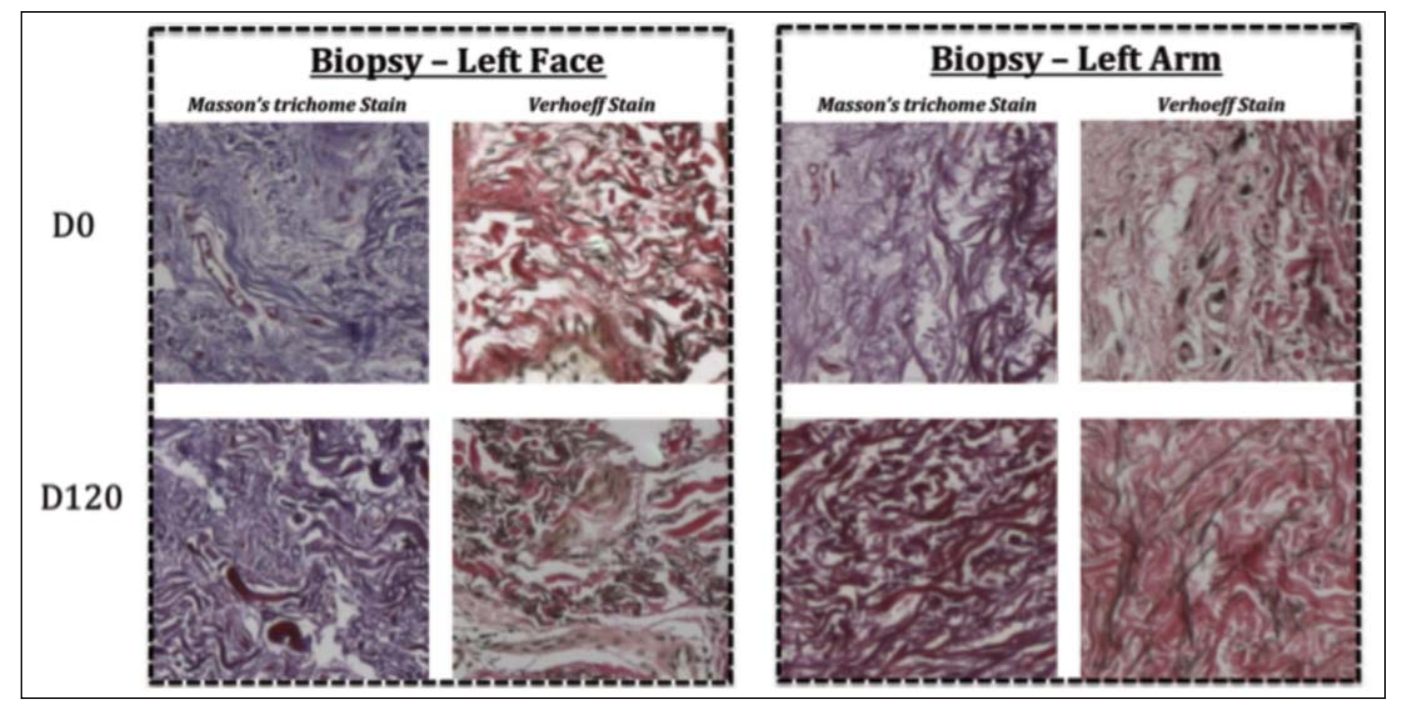

Figure 2: Collagen and elastic fibers proliferation observed with Masson's trichrome and verhoeff stains after 120 days of study show an antioxidant activity greater than that with vitamins $\mathrm{E}$ and $\mathrm{C} .{ }^{25}$

In relation to the reduction of the facial sebum of $29.26 \%$, obtained at the end of the study, we could not at present find any references in the literature to explain this effect. This finding deserves further studies regarding specific effective components.

For the analysis of the dermal density by ultrasound, we noted that there was a continuous gradual increase of density values during the period of the use of the product (face: 50\%, p<0,001; arm: $14 \%$, $\mathrm{p}=0.002)$ ) (Table 2 and Graphic 4). This effect is also well characterized by the density images obtained from the Ultrasound device display (Graphic 1).
Probably the vitamin $\mathrm{C}$, also present in the supplement complex of the study, could have played a contributing role to the result. It provides aesthetic results to the skin upon its oral use, as it has the capacity of increasing the stability and reducing the collagen's thermal sensibility, stimulating the production of collagen both in vitro and in vivo, and protecting the skin against UV-induced photodamage. ${ }^{15}$ Such clinical results can be explained by the fact that vitamin $\mathrm{C}$ is a cofactor for propyl and lysyl hydroxylases, which, respectively, form hydroxyproline and hydroxylysine, essential for the secretion of procollagen by fibroblasts, as, in vitro, it increases the expression of collagen expression genes. ${ }^{24,26-30}$

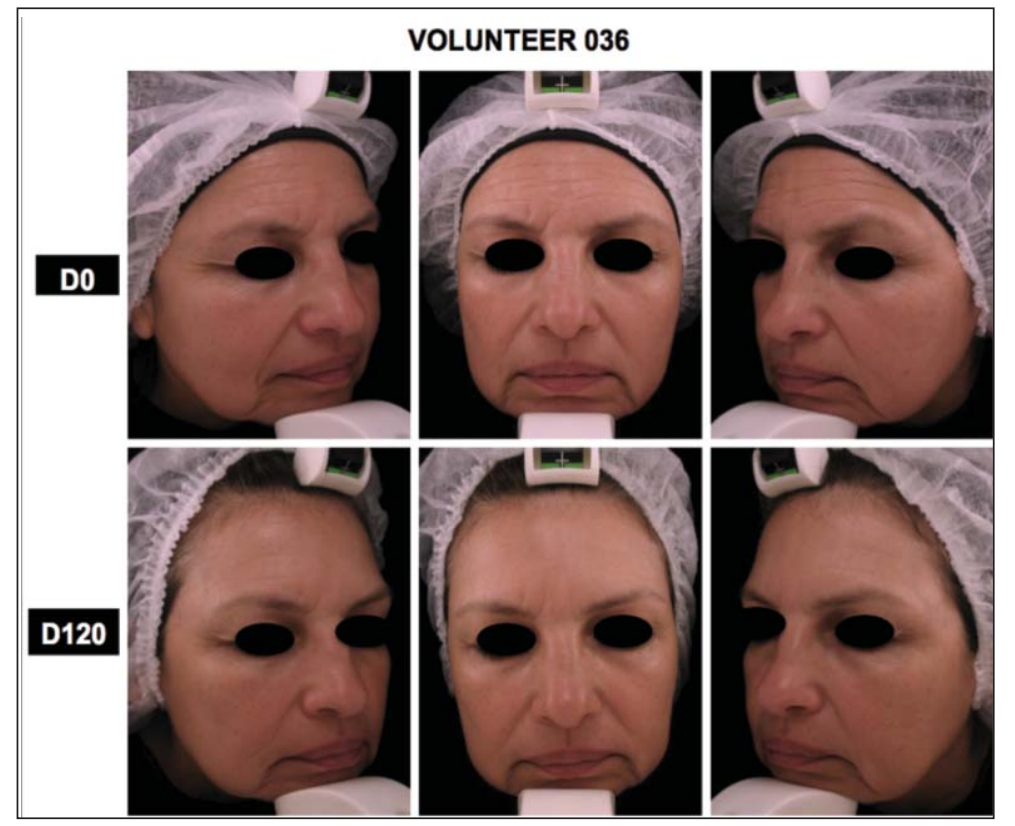

Figure 3: Volunteer's clinical evolution with use of Imedeen ${ }^{\circledast}$ time perfection for 120 days observed through photography

Note: Improvement in depth of periorbicular, forehead, glablellar wrinkles and nasolabial folds are observed in the picture when D120 (final study time) is compared to DO (prior to the study). 
This collagen stimulation with 120 days of use of the nutraceutical in the study could be confirmed by the histological changes observed through Massons trichrome staining. This fact is in accordance with the literature. ${ }^{24,26-30}$ Nevertheless, in this study, proliferation of the elastic fibers was noted as well as that of the collagen, a piece of information that can be considered new in literature (Graphic 5 and Figure 2).

\section{CONCLUSION}

It may be concluded from this study that a daily intake of a nutraceutical composed of lycopene, acerola extract, grape seed extract and Biomarine Complex ${ }^{\mathrm{TM}}$ indeed improves the cutaneous signs standards of photoaging, and also contributes to maintain skin hydration, acidity balance of the skin, reduction of facial seborrhea and to an increase of dermal density, as assessed by ultrasound.

\section{REFERENCES}

1. Montagner S, Costa A. Bases biomoleculares do fotoenvelhecimento. An Bras Dermatol. 2009;84:263-9.

2. Bogdan Allemann I, Baumann L. Antioxidants used in skin care formulations. Skin Therapy Lett. 2008;13:5-9.

3. Rijken F, Bruijnzeel PL. The pathogenesis of photoageing: the role of neutrophils and neutrophil-derived enzymes. J Investig Dermatol Symp Proc. 2009;14:67-72.

4. Yaar M, Gilchrest BA. Skin aging: postulated mechanisms and consequent changes in structure and function. Clin Geriatr Med. 2001;17:617-30.

5. Landau M. Exogenous factors in skin ageing. Curr Probl Dermatol. 2007;35:1-13.

6. Duarte-Almeida JM, Santos RJ, Genovese MI, Lajolo FM. Avaliação da atividade antioxidante utilizando sistema $\beta$-caroteno/ácido linoléico e método de seqüestro de radicais dpph. Ciênc Tecnol Aliment. 2006;26:446-52.

7. Amara-Mokrane YA, Lehucher-Michel MP, Balansard G, Duménil G, Botta A. Protective effects of alpha-hederin, chlorophyllin and ascorbic acid towards the induction of micronuclei by doxorubicin in cultured human lymphocytes. Mutagenesis. 1996;11:161-7.

8. Lupulescu A. Estrogen use and cancer risk: a review. Int J Vitam Nutr Res. 1994;64:3-14.

9. Duthie SJ, Ma A, Ross MA, Collins AR. Antioxidant supplementation decreases oxidative DNA damage in human lymphocytes. Cancer Res. 1996;56:1291-5.

10. Liu C, Lian F, Smith DE, Russell RM, Wang XD. Lycopene supplementation inhibits lung squamous metaplasia and induces apoptosis via up-regulating insulin-like growth factor-binding protein 3 in cigarette smoke-exposed ferrets. Cancer Res. 2003:63:3138-44

11. Shami NJIE, Moreira EAM. Licopeno como agente antioxidante. Rev Nutr. 2004:17:227-36

12. Aust $\mathrm{O}$, Stahl W, Sies H, Tronnier H, Heinrich U. Supplementation with tomato-based products increases lycopene, phytofluene, and phytoene levels in human serum and protects against UV-light-induced erythema. Int J Vitam Nutr Res. 2005;75:54-60.

13. Sato M, Bagchi D, Tosaki A, Das DK. Grape seed proanthocyanidin reduces cardiomyocyte apoptosis by inhibiting ischemia/reperfusion-induced activation of JNK-1 and C-JUN. Free Radic Biol Med. 2001;31:729-37.

14. Tebib K, Rouanet JM, Besancon P. Antioxidant effects of dietary polymeric grape seed tannins in tissues of rats fed a high cholesterol-vitamin E-deficient diet. Food Chem. 1997;59:135-41.

15. Heule F. An oral approach to the treatment of photodamaged skin: a pilot study. J Int Med Res. 1992;20:273-8.

16. Kieffer ME, Efsen J. Imedeen in the treatment of photoaged skin: an efficacy and safety trial over 12 months. J Eur Acad Dermatol Venerol. 1998;11:129-36.

17. Kohen R. Skin antioxidants: their role in ageing and in oxidative stress - new approaches for their evaluation. Biomed Pharmacother. 1999:53:181-92.

18. Kohen R, Gati I. Skin low molecular antioxidants and their role in ageing and in oxidative stress. Toxicol. 2000;148:149-57.
19. Lange Skovgaard GR, Jensen AS, Sigler ML. Effect of a novel dietary supplement on skin aging in post-menopausal women. Eur J Clin Nutr. 2006:60:1201-6.

20. Sigler ML, Stephens TJ, Truelsen KM, Rasmussen P. A placebo controlled study of an oral supplement in improving the appearance of photoaged skin. J Am Acad Dermatol 2004;50 Suppl 1:P26.

21. Costa A. Hidratação cutânea. RBM Rev Bras Med. 2009;66:15-21.

22. Costa A, Pires MC, Gonçalves HS, Gontijo B, Becelli L. Estudo clínico observacional de eficácia e segurança do uso de extratos de Imperata cylindrica e de Triticum vulgare. RBM Rev Bras Med. 2009;66:249-53.

23. Mauro TM. SC pH: Measurement, Origins, and Functions. In: Elias PM, Feingold KR. Skin Barrier. New York: Taylor \& Francis Group; 2006. p.223-229.

24. Darvin M, Patzelt A, Gehse S, Schanzer S, Benderoth C, Sterry W, et al. Cutaneous concentration of lycopene correlates significantly with the roughness of the skin. Eur J Pharm Biopharm. 2008:69:943-7.

25. Miller NJ, Rice-Evans C, Davies MJ, Gopinathan V, Milner A. A novel method for measuring antioxidant capacity and its application to monitoring the antioxidant status in premature neonates. Clin Sci. 1993:84:407-12

26. Dehm P, Prockop DJ. Synthesis and extrusion of collagen by freshly isolated cells from chick embryo tendon. Biochim Biophys Acta. 1971;15:358-69.

27. Berg RA, Prockop DJ. The termal transition of a non-hydroxylated from collagen: evidence for the role of hydroxyproline in stabilizing the triple helix of collagen. Biochem Biophys Res Commun. 1973:52:115-20.

28. Phillips CL, Combs SB, Pinnell SR. Effects of ascorbic acid on proliferation and collagen synthesis in relation to the donor age of human dermal fibroblasts. J Invest Dermatol. 1994;103:228-32

29. Hata RI, Senoo H. L-ascorbic acid 2-phosphate stimulates collage accumulation, cell proliferation, and formation of a three-dimensional tissue-like substance by skin fibroblasts. J Cell Physiol. 1989;138:8-16.

30. Hering TM, Kollar J, Huynh TD, Varelas JB, Sandell LJ. Modulation of extra-cellular matrix gene expression in bovine high-density chondrocyte cultures by ascorbic acid and enzymatic resuspension. Arch Biochem Biophys. 1994;314:90-8.

MAILING ADDRESS / ENDEREÇO PARA CORRESPONDÊNCIA:
Adilson Costa
Alameda Franca, 760 ap. 21 -Jd. Paulista
O1422-000 São Paulo/SP - Brasil
Tel.: +55 1130341170
E-mail: adilson_costa@botmail.com

How to cite this article/Como citar este artigo: Costa A, Lindmark L, Arruda LHF, Ota FS, Assumpção EC. Clinical, biometric and ultrasound assessment of the effects of daily use of a nutraceutical composed of lycopene, acerola extract, grape seed extract and Biomarine Complex in photoaged human skin. An Bras Dermatol. 2012;87(1):52-61. 